\title{
UPAYA GURU MATA PELAJARAN IPS DALAM MENANAMKAN KARAKTER DISIPLIN DAN TANGGUNG JAWAB SISWA
}

\author{
Amiruddin ${ }^{1}$, Muhammad Widda Djuhan ${ }^{2}$ \\ ${ }^{1}$ Institut Agama Islam Negeri Ponorogo \\ amir.el.ghibran28@gmail.com \\ ${ }^{1}$ Institut Agama Islam Negeri Ponorogo \\ djuhan@iainponorogo.ac.id
}

\begin{abstract}
ABSTRAK
Latar belakang penelitian ini berawal dari ditemukan kurangnya sikap disiplin dan tanggung tanggung jawab siswa kelas VIII C SMP Negeri 1 Jenangan. Dari hasil observasi yang peneliti laksanakan pada tanggal 17 Oktober dan 24 Oktober 2020 ditemukan sebanyak 53\% siswa dari jumlah siswa kelas VIII C yaitu 30 siswa tidak mengerjakan tugas pada mata pelajaran IPS Terpadu. Penelitian ini bertujuan untuk mengetahui dan menganalisis upaya guru mata pelajaran IPS dalam menanamkan karakter disiplin dan tanggung jawab siswa melalui pembelajaran IPS Terpadu di kelas VIII C SMP Negeri 1 Jenangan. Penelitian ini menggunakan metode penelitian kualitatif. Teknik analisis yang digunakan dalam penelitian ini adalah teknik analisis deskriptif. Hasil penelitian ditemukan bahwa upaya guru mata pelajaran IPS dalam menanamkan karakter disiplin dan tanggung jawab yaitu melalui prinsip Contextual Teaching and Learning (CTL) yang dimana guru mengkaitkan antara materi yang dipelajarinya dengan situasi dunia nyata siswa. Beberapa kendala dalam penanaman karakter disiplin dan tanggung jawab tersebut, yaitu antara lain a) Faktor keluarga, b) Faktor lingkungan, c) Pembelajaran daring, d) Faktor dari diri siswa. Sedangkan solusi dari adanya kendala dalam penanaman karakter displin dan tanggung jawab tersebut yaitu melalui, a) Kontrol dari kepala sekolah, b) Peran aktif guru
\end{abstract}

Kata Kunci: Karakter, Displin, Tanggung Jawab, Pembelajaran IPS Terpadu

\section{ABSTRACT}

The background of this research begins with the finding of a lack of discipline and 
responsibility in class VIII C students of SMP Negeri 1 Jenangan. From the results of observations carried out by researchers on October 17 and October 24, 2020, it was found that $53 \%$ of students from class VIII C, namely 30 students did not do assignments in Integrated Social Studies subjects. This study aims to identify and analyze the efforts of social studies teachers in instilling the character of discipline and responsibility in students through integrated social studies learning in class VIII C of SMP Negeri 1 Jenangan. This study used qualitative research methods. The analytical technique used in this research is descriptive analysis technique. The results of the study found that the efforts of social studies teachers in instilling the character of discipline and responsibility were through the principle of Contextual Teaching and Learning (CTL) in which the teacher linked the material he studied with students' real world situations. Some of the obstacles in inculcating the character of discipline and responsibility, which include a) family factors, b) environmental factors, c) online learning, d) factors from students. While the solution to the obstacles in planting the character of discipline and responsibility is through, a) Control from the principal, b) Active role of teachers.

Keywords: Character, Discipline, Responsibility, Integrated Social Studies Learning

\section{PENDAHULUAN}

Pendidikan adalah investasi suatu bangsa, bekal hidup dan kehidupan manusia dimasa kini dan masa yang akan datang, dan pendidikan memiliki pengaruh terhadap semua aspek kehidupan. Oemar Hamalik mengatakan bahwa pendidikan adalah suatu proses dalam rangka mempengaruhi siswa agar dapat menyesuaikan diri sebaik mungkin terhadap lingkungannya dan dengan demikian akan menimbulkan perubahan dalam dirinya yang memungkinkannya untuk berfungsi dalam kehidupan masyarakat. ${ }^{1}$

Dalam era ini, pendidikan bukan hanya sekedar transfer konowledge akan tetapi pendidikan juga harus mampu membangun peserta didik menjadi pribadi yang memiliki sikap yang mulia. Jadi pendidikan bukan hanya terkait dengan kecerdasan secara intelektual, akan tetapi pendidikan juga harus mampu membentuk karakter dari peserta didik menjadi pribadi yang mulia dalam membangun masyarakat yang berperadaban (civil society). Seperti mengutip perkataan dari filsuf Yunani yaitu Plato dalam Fatchul Mu'in "jika anda bertanya apa manfaat pendidikan, maka jawabannya sederhana, pendidikan menjadikan orang menjadi lebih baik dan orang baik tentu berperilaku mulia”. ${ }^{2}$

Pendidikan karakter merupakan salah satu tujuan penting dari Pendidikan Nasional Indonesia. Undang-Undang Nomor 20 Tahun 2003 tentang Sistem

1 Oemar Hamalik, Proses Belajar Mengajar (Jakarta: Bumi Aksara, 2012), 79.

2 Fatchul Mu'in, Pendidikan Karakter: Kontruksi Teoritik dan Praktik (Yogyakarta: ArRuzz Media, 2011), 21. 
Pendidikan Nasional (SISDIKNAS) Pasal 3 menyebutkan bahwa pendidikan nasional berfungsi mengembangkan kemampuan dan membentuk watak serta peradaban bangsa yang bermartabat dalam rangka mencerdaskan kehidupan bangsa, bertujuan untuk berkembangnya potensi peserta didik agar menjadi manusia yang beriman dan bertakwa kepada Tuhan Yang Maha Esa, berakhlak mulia, sehat, berilmu, kreatif, mandiri, dan menjadi warga negara yang demokratis serta bertanggung jawab. ${ }^{3}$

Pendidikan karakter sebagai wahana dalam menanamkan nilai- nilai moral dan karakter bagi peserta didik, dewasa ini tengah mengalami kemerosotan moral dan karakter atau disebut dengan istilah dekadensi moral. Dekadensi moral peserta didik salah satunya diakibatkan oleh kurangnya penanaman nilai-nilai moral di institusi pendidikan. Implementasi pendidikan kita di lapangan lebih banyak berfokus kepada pencapaian dalam ranah kognitif (pengetahuan) dan psikomotorik (ketrampilan) saja, dan mengesampingkan terdahap penanaman nilai-nilai karakter dalam ranah afektif (sikap). Kehadiran kurikulum 2013 revisi sebenarnya mencoba menselaraskan dan menyeimbangkan dari 3 ranah tersebut, akan tetapi implementasinya masih seringkali kita temui hanya berfokus kepada ranah kognitif (pengetahuan).

Salah satu unsur dalam karakter adalah sikap. Sikap seseorang tersebut akan dilihat dan akan dinilai oleh orang lain bagaimanakah karakter dari orang tersebut. Bahkan dari sikap tersebut orang lain cenderung akan menilai karakter dari orang tersebut, sebab sikap merupakan cerminan dari karakter seseorang, walaupun yang dilihat dan dinilai orang lain tersebut belum tentu benar. Dalam PERMENDIKBUD No. 54 tahun 2013 tentang Standar Kompetensi Lulusan SMP/MTs salah satunya yaitu terkait dengan sikap dan memiliki kualifikasi kemampuan yang diharapkan yaitu memiliki perilaku yang mencerminkan sikap orang yang beriman, berakhlak mulia, berilmu, percaya diri, dan bertanggung jawab.

Beberapa unsur dalam karakter yaitu antara lain sikap disiplin dan tanggung jawab. Disiplin merupakan tindakan yang menujukkan perilaku tertib dan patuh pada berbagai ketentuan dan peraturan. Adapun dari indikator disiplin tersebut yaitu membiasakan hadir tepat waktu, membiasakan mematuhi aturan. Begitu halnya dengan tanggung jawab yang merupakan sikap dan perilaku seseorang untuk melaksanakan tugas dan kewajibannya yang seharusnya dia lakukan. Indikator dari tanggung jawab antara lain melaksanakan tugas piket secara teratur, peran serta aktif dalam kegiatan sekolah.

Dalam proses pembelajaran di kelas tentunya setiap mata pelajaran memiliki karakteristik yang berbeda-beda, akan tetapi setiap mata pelajaran tersebut

3 Undang-Undang Nomor 20Tahun 2003tentang Sistem Pendidikan Nasional (Sisdiknas) Pasal 3. 
memiliki peran yang penting dalam menyiapkan diri peserta didik dalam keberlangsungan kehidupan di masyarakat. Salah satunya yaitu mata pelajaran IPS Terpadu. Mata pelajaran IPS pada tingkat pendidikan SMP/MTs mempunyai karakteristik tersendiri yang berbeda dengan mata pelajaran lainnya karena berasal dari perpaduan disiplin ilmu sosial yaitu Sosiologi, Geografi, Sejarah, dan Ekonomi. Oleh karena itulah, ruang lingkup yang menjadi pembahasan pada mata pelajaran ini sangatlah luas, ini disebabkan masing-masing disiplin ilmu mempunyai dimensi yang berbeda sebagai objek pembahasan. Akan tetapi, keempat disiplin ilmu tersebut memiliki kesamaan mengenai sosial, sehingga mata pelajaran IPS ditingkat SMP dikenal dengan istilah IPS Terpadu.

Jika ditinjau dari karakteristik mata pelajaran IPS terpadu yang telah diuraikan di atas, diketahui bahwa mata pelajaran ini memiliki peranan penting dalam proses penguatan karakter. Hal ini disebabkan adanya kemampuan pribadi dan sosial dalam penguasaan karakteristik nilai-nilai sebagai pribadi dan sebagai warga masyarakat serta kemampuan untuk hidup bermasyarakat. Melalui pembelajaranIPS terpadu, peserta didik dibina dan dibimbing untuk meningkatkan kemampuan mental-intelektualnya menjadi masyarakat yang berketerampilan dan berkepedulian sosial serta memiliki rasa tanggung jawab terhadap sesama. ${ }^{4}$

Sekolah Menengah Pertama Negeri 1 Jenangan merupakan lembaga pendidikan formal yang program pendidikannya dilaksanakan selama tiga tahun setelah melewati jenjang Sekolah Dasar selama 6 tahun. SMP Negeri 1 Jenangan ini memiliki beberapa tujuan diantaranya yaitu: 1) Pengembangan Kompetensi Lulusan, 2) Pengembangan Standar Isi, 3) Pengembangan Standar Proses, 4) Pengembangan Pendidik dan Tenaga Kependidikan, 5) Pengembangan Sarana dan Prasarana Sekolah, 6) Pengembangan Standar Pengelolaan, 7) Pengembangan Standar Pembiayaan, 8) Pengembangan dan Implementasi Sistem Penilaian.

Penanaman pendidikan karakter di SMP Negeri 1 Jenangan selama ini telah diterapkan dan ditanamkan kepada peserta didik. Upaya penanaman pendidikan karakter di SMP Negeri 1 Jenangan salah satunya terlihat pada kegiatan yaitu pada setiap pagi di area gerbang pintu masuk sekolah yaitu guru di SMP Negeri 1 Jenangan menerapkan 3S (Senyum, Salam, dan Sapa) kepada peserta didik yang baru tiba di sekolah serta mengecek atribut dan kerapian siswa sebagai bentuk penerapan kedisiplinan kepada siswa.

Berdasarkan hasil observasi awal yang peneliti amati di kelas VIII C SMP Negeri 1 Jenangan, peneliti menemukan terkait dengan kurangnya sikap disiplin dan tanggung tanggung jawab siswa. Dari hasil observasi yang peneliti laksanakan

4 Dwi Sartika, Eva, dan Cik Ima, "Implementasi Nilai-Nilai Karakter Dalam Pembelajaran IPS Terpadu di SMP Utama Bakti Palembang," Prosding Seminar Nasional 20 Program Pascasarjana Universitas PGRI Palembang, 25 November 2017, 61. 
pada tanggal 17 Oktober dan 24 Oktober 2020 ditemukan sebanyak 53\% siswa dari jumlah siswa kelas VIII C yaitu 30 siswa tidak mengerjakan Tugas pada mata pelajaran IPS Terpadu. Hal tersebut diperkuat berdasarkan hasil wawancara yang peneliti lakukan dengan Ibu Siti Supatmi (Guru mata pelajaran IPS Terpadu dan wali kelas VIII C) tanggal 12 November 2020 diperoleh informasi bahwa siswa kelas VIII C SMP Negeri 1 Jenangan kurang memiliki respon terhadap mata pelajaran IPS Terpadu. ${ }^{5}$

Sebenarnya saat proses pembelajaran guru telah menanamkan nilai-nilai sikap disiplin dan tanggung jawab dalam upaya membentuk karakter dalam diri siswa tersebut. Hal ini dapat terlihat berdasarkan hasil pengamatan yang peneliti laksanakan di kelas VIII C SMP Negeri 1 Jenangan, terlihat bahwa guru mata pelajaran IPS terpadu di SMP Negeri 1 Jenangan telah menanamkan sikap tanggung jawab kepada peserta didik. Penanaman sikap disiplin dan tanggung jawab terlihat pada saat guru mata pelajaran IPS Terpadu, Ibu Siti Supatmi memasuki kelas VIII C dan melihat kelas berantakan dan kotor. Maka guru tersebut memberikan teguran kepada siswa yang bertugas piket kelas pada saat itu serta meminta siswa tersebut untuk menjalankan tanggung jawabnya dalam membersihkan kelas.

Berdasarkan permasalahan di atas dari hasil temuan pada observasi awal yang peneliti lakukan di kelas VIII C dalam proses pembelajaran IPS Terpadu di SMP Negeri 1 Jenangan, terdapat berbagai permasalahan dalam upaya penanaman karakter disiplin dan tanggung jawab siswa. Peniliti mencoba mengidentifikasi dari hasil temuan permasalahan tersebut. Oleh karena itu peneliti tertarik untuk mengkaji lebih mendalam dan mengetahui terkait upaya penanaman karakter disiplin dan tanggung jawab siswa di SMP Negeri 1 Jenangan, maka dalam penelitian ini peneliti mengangkat judul: "Upaya Guru Mata Pelajaran IPS dalam Menanamkan Karakter Disiplin dan Tanggung Jawab Siswa di SMP Negeri 1 Jenangan Ponorogo".

Tujuan dari penelitian ini adalah: 1) Untuk mengetahui dan mampu menganalisis pelaksanaan penanaman karakter disiplin dan tanggung jawab siswa melalui guru mata pelajaran IPS Terpadu di SMP Negeri 1 Jenangan, 2) Untuk mengetahui dan mendeskripsikan kendala yang dihadapi dan solusi yang diberikan oleh sekolah dan guru mata pelajaran IPS Terpadu dalam upaya penanaman karakter disiplin dan tanggung jawab siswa di SMP Negeri 1 Jenangan.

Manfaat yang penulis harapkan dari penulisan penelitian ini adalah: 1) Secara teoritis; (a) Sebagai sumbangan pemikiran ilmu pengetahuan bagi lembaga- lembaga pendidikan di Indonesia, (b) Menambah dan memperkaya

5 Wawancara dengan Ibu Siti Supatmi pada hari jumat pagi tanggal 12 November 2020. 
khazanah keilmuan dunia pendidikan, (c) Sebagai sumbangan data ilmiah di bidang pendidikan dan disiplin ilmu lainnya, khususnya bagi Jurusan Tadris Ilmu Pengetahuan Sosial Fakultas Tarbiyah dan Ilmu Keguruan IAIN Ponorogo. 2) Secara Praktis; (a) Untuk SMPN 1 Jenangan, peneliti berharap melalui penelitian ini SMP Negeri 1 Jenangan dapat memperoleh masukan serta informasi yang konkrit sebagai titik tolak ukur dalam usaha peningkatan pengajaran IPS Terpadu dalam hal penanaman karakter siswa di SMP Negeri 1 Jenangan, (b) Untuk pendidik, sebagai bahan masukan bagi guru mata pelajaran IPS Terpadu dalam hal penanaman karakter siswa di SMP Negeri 1 Jenangan, (c) Untuk peneliti sendiri, mendapatkan pengalaman, pengetahuan dan wawasan yang luas serta bisa digunakan sebagai wahana untuk mengetahui tipologi pendidikan sekaligus sebagai bekal saat nanti peneliti terjun ke dunia pendidikan. (c) Untuk penulis lain, untuk memberikan inspirasi sekaligus motivasi bagi peneliti lain, khususnya mahasiswa IAIN Ponorogo untuk melakukan penelitian lebih lanjut yang terkait dengan gagasan peneliti.

\section{METODE PENELITIAN}

Penelitian ini menggunakan metode penelitian kualitatif, yaitu peneliti sebagai sumber utama penelitian dalam proses wawancara, observasi, dan dokumentasi. Subjek penelitian adalah guru mata pelajaran IPS Terpadu dalam upayanya menanamkan karakter disiplin dan tanggung jawab siswa dalam proses pembelajaran IPS Terpadu kelas VIII C di SMP Negeri 1 Jenangan tahun ajaran 2020/2021. Pengumpulan data dilakukan dengan teknik wawancara, observasi, dan dokumentasi. Instrument yang digunakan dalam penelitian ini berupa manusia, yaitu peneliti sendiri. Untuk menjaga keabsahan data, digunakan teknik perpanjangan keikutsertaan, pengamatan tekun dan triangulasi. Teknik analisis data yang digunakan dalam penelitian ini adalah teknik analisis deskriptif, dengan menggunakan konsep Miles dan Hubermen dengan tiga tahapan yaitu reduksi data, penyajian data dan penarikan kesimpulan.

\section{HASIL DAN PEMBAHASAN}

1. Upaya Guru Mata Pelajaran IPS dalam Menanamkan Karakter Disiplin dan Tanggung Jawab Siswa di SMP Negeri 1 Jenangan

Penanaman adalah proses, cara, atau perbuatan menanam, menanami, atau menanamkan. ${ }^{6}$ Penanaman yang dimaksud di dalam penelitian ini adalah cara yang dilakukan oleh sekolah dalam menanamkan karakter kepada siswa. Karakter secara umum diasosiasikan sebagai temperamen yang memberinya

6 Depertemen Pendidikan Nasional, Kamus Besar Bahasa Indonesia (Jakarta: Balai Pustaka, 2007), 1135. 
sebuah definisi yang menekankan pada unsur psikososial. ${ }^{7}$ Karakter dianggap sama dengan kepribadian sebagai ciri atau karakteristik atau sifat khas dari diri seseorang yang bersumber pada bentukan-bentukan yang diterima dari lingkungan, misalnya keluarga. ${ }^{8}$

Karakter menurut Pusat Bahasa DEPDIKNAS adalah "bawaan, hati, kepribadian, budi pekerti, perilaku, personalitas, sifat, tabiat, temperamen, watak". Kamus Besar Bahasa Indonesia, belum memasukan kata karakter, yang ada adalah kata "watak" yang diartikan sebagai sifat batin manusia yang memengaruhi segenap pikiran dan tingkah laku, budi pekerti dan tabiat. ${ }^{9}$

Desain Pendididkan Karakter: Konsep dan aplikasinya dalam lembaga pendidikan" menyatakan bahwa karakter adalah cara berpikir dan berprilaku yang menjadi ciri khas tiap individu untuk hidup dalam bekerja sama, baik dalam lingkup keluarga, masyarakat, bangsa, dan negara. Individu yang berkarakter baik adalah individu yang bisa membuat keputusan dan siap mempertanggungjawabkan tiap akibat dari keputusan yang ia buat. ${ }^{10}$ Karakter merupakan nilai-nilai perilaku manusia yang berhubungan dengan Tuhan Yang Maha Esa, diri sendiri, sesama manusia, lingkungan, dan kebangsaan yang terwujud dalam pikiran, sikap, perasaan, perkataan dan perbuatan berdasarkan norma-norma agama, hukum, tata krama, budaya, dan adat istiadat. ${ }^{11}$ Pendidikan karakter merupakan upaya untuk mengarahkan perilaku manusia menuju nilai-nilai kehidupan. ${ }^{12}$ Pendidikan karakter bertujuan untuk membentuk dan membangun pola pikir, sikap, dan perilaku siswa agar menjadi positif, bermoral, berakhlak mulia, dan bertanggung jawab. ${ }^{13}$

Penanaman karakter merupakan suatu proses dalam menumbuhkan, menanamkan dan mengembangkan nilai-nilai luhur kepada peserta didik agar senantiasa melaksanakan tugas dan kewajibannya yang dilandasi dengan sikap disiplin dan penuh tanggung jawab. Pelaksanaan penanaman karakter disiplin dan tanggung jawab siswa dalam proses pembelajaran IPS Terpadu

7 Novan Ardy Wiyani, Pendidikan Karakter Berbasis Iman dan Taqwa (Yogyakarta: Teras, 2012), 3 .

8 Doni Koesoema, Pendidikan Karakter Strategi Mendidik Anak di Zaman Global (Jakarta: PT Gramedia Widiasarana Indonesia, 2007), 79-80.

9 Kamus Besar Bahasa Indonesia (Departemen Pusat Bahasa Depdiknas, 2008).

10 Zubaedi, Desain Pendidikan Karakter: Konsep dan Aplikasinya dalam Lembaga Pendidikan (Jakarta: Kencana Prenandamedia Group, 2011), 11.

11 Masnur Muslich, Pendidikan Karakter Menjawab Tantangan Krisis Multidimensional (Jakarta: Bumi Aksara, 2011), 84.

12 Mustoip dan Sofyan, "Implementation of Character Education," International Journal Pedagogy of Social Studies, 1 (2018): 54.

${ }_{13}$ Novitasari, Wiyanarti Erlina, dan Jupri, "The Implementation of Project Based Learning To Improve Students Responsibility in Social Studies Learning," International Journal Pedagogy of Social Studies, 2 (2018): 20. 
kelas VIII C di SMP Negeri 1 Jenangan sudah ditanamkan secara baik kepada peserta didik.

Penanaman karakter disiplin dan tanggung jawab di SMP Negeri 1 Jenangan berdasarkan hasil penelitian yang peneliti peroleh dari hasil wawancara, observasi maupun dokumentasi di SMP Negeri 1 Jenangan. Terlihat bahwa penanaman karakter disiplin dan tanggung jawab telah ditanamkan, hal itu tercermin dari siswa-siswi kelas VIII C SMP Negeri 1 Jenangan yang datang tepat waktu di sekolah ketika pembelajaran tatap muka secara terbatas dilaksanakan. Dalam proses pembelajaran tersebut, siswa-siswi kelas VIIIC SMP Negeri 1 Jenangan disiplin dalam mentaati protokol kesehatan yaitu dengan selalu memakai masker dan menjaga jarak ketika proses pembelajaran maupun di lingkungan sekolah dan diharuskan mencuci tangan sebelum masuk ke dalam kelas. Hal tersebut, merupakan contoh penanaman kedisiplinan dan tanggung jawab yang telah ditanamkan di SMP Negeri 1 Jenangan.

Penanaman karakter disiplin dan tanggung jawab pada proses pembelajaran IPS Terpadu di kelas VIII C SMP Negeri 1 Jenangan merupakan bentuk dari contoh dan teladan yang diberikan oleh Bapak/Ibu guru baik dalam proses mengajar di dalam kelas maupun pada saat di luar kelas. Penamanan karakter disiplin dan tanggung jawab juga terlihat dari lingkungan SMP Negeri 1 Jenangan yang selalu terlihat bersih, hijau, rindang, indah, tamannya terlihat sangat tertata dengan rapi dan sekitar lingkungan SMP Negeri 1 Jenangan juga di pasang papan-papan aturan dan kata-kata motivasi pengingat untuk peserta didiknya. Selain itu juga terlihat gazebo dan tempat duduk yang sangat tertata dengan rapi yang bisa digunakan siswa dalam belajar di luar kelas ataupun untuk aktivitas lainnya di luar kelas. Terdapat juga aturan yang terkait dengan disiplin dalam mentaati aturan protokol kesehatan. Kebersihan dan keindahan tersebut tidak terlepas dari kedisiplinan dan tanggung jawab semua warga sekolah dalam menjaga keasrian SMP Negeri 1 Jenangan

Selain itu, dalam proses pembelajaran mata pelajaran IPS Terpadu yang dilaksanakan secara daring di kelas VIII C SMP Negeri 1 Jenangan. Ditemukan hasil bahwa siswa-siswi kelas VIII C SMP Negeri 1 Jenangan juga memiliki kedisiplinan dalam mengumpulkan tugas, dan mengikuti kegiatan pembelajaran. Dalam penyusunan silabus dan RPP mata pelajaran IPS Terpadu yang berkaitan dengan pelaksanaan pendidikan karakter dimana nantinya bisa membentuk sikap disiplin dan tanggungjawab yaitu dilakukan dengan cara mengembangkan silabus dan RPP yang berbasis pendidikan karakter.

Upaya dan strategi dalam penanaman karakter disiplin dan tanggung jawab yaitu dengan melalui prinsip CTL. Contextual Teaching and Learning 
(CTL) merupakan konsep belajar yang membantu guru dalam mengkaitkan antara materi yang dipelajarinya dengan situasi dunia nyata siswa dan mendorong siswa membuat hubungan antara pengetahuan yang dimilikinya dengan penerapannya dalam kehidupan sehari-hari dengan melibatkan tujuh komponen pembelajaran efektif. ${ }^{14}$ Dengan melalui prinsip Contextual Teaching and Learning (CTL) yaitu mengaitkan materi pembelajaran dengan situasi yang ada dalam dunia nyata sehingga peserta didik akan dengan mudah memahami dan menangkap materi pembelajaran serta dapat mengetahui contoh yang baik dan tidak baik yang tentunya dapat menanamkan karakter ke dalam diri peserta didik.

Meskipun telah ditanamkan nilai karakter displin dan tanggung jawab di SMP Negeri 1 Jenangan, masih dapat ditemukan beberapa siswa kelas VIII C yang belum menerapkan nilai-nilai kedisiplinan dan tanggung jawab tersebut. Hal tersebut terlihat dari beberapa siswa yang telambat dalam pengumpulan tugas dan tidak mengikuti kegiatan pembelajaran secara daring pada mata pelajaran IPS Terpadu. Oleh karena itu, penanaman karakter disiplin dan tanggung jawab harus terus di evaluasi, diperbaiki dan ditingkatkan agar kedisiplinan dan tanggung jawab siswa tersebut berdampak terhadap prestasi siswa-siswi kelas VIII C SMP Negeri 1 Jenangan.

\section{Kendala dalam Penanaman Karakter Disiplin dan Tanggung Jawab Siswa dalam Proses Pembelajaran IPS Terpadu Kelas VIIIC di SMP Negeri 1 Jenangan}

Pendidikan karakter harus dikembangkan melalui pendekatan yang komprehensif, menggunakan semua aspek persekolahan sebagai peluang untuk pengembangan karakter. ${ }^{15}$ Sehingga hal tersebut dapat menanamkan nilai-nilai tanggung jawab kepada siswa.

Urgensi membangun karakter dijelaskan dalam buku karya Syamsul Kurniawan bahwa pembangunan karakter adalah usaha paling penting yang pernah diberikan kepada manusia. Pembangunan karakter adalah tujuan luar biasa dari sistem pendidikan yang benar. Pendidikan keluarga maupun pendidikan dalam sekolah, orang tua, dan guru tetap sadar bahwa pembangunan tabiat yang agung adalah tugas mereka. ${ }^{16}$

14 Nurhadi, Pembelajaran Kontekstual (Contextual Teaching /CTL) dan Penerapannya dalam KBK (Malang: Universitas Negeri Malang, 2004), 5.

15 Zubaedi, Desain Pendidikan Karakter: Konsep dan Aplikasinya dalam Lembaga Pendidikan, 117.

16 Syamsul Kurniawan, Pendidikan Karakter: Konsepsi dan Implementasi secara Terpadu di Lingkungan Keluarga, Sekolah, Perguruan Tinggi, dan Masyarakat (Yogyakarta: Ar-Ruzz Media, 2013), 31. 
Berdasarkan yang peneliti amati tidak sedikit siswa yang tidak mencerminkan nilai-nilai karakter yaitu tidak ada sikap tanggung jawab atas tugas yang diberikan guru. Sementara itu, Syamsul Kurniawan menjelaskan mengajari peserta didik tanggung jawab adalah hal yang tidak mudah untuk dilakukan oleh guru manapun. Namun, hal itu sangat penting untuk dilakukan karena pentingnya bagi seseorang untuk memiliki sifat dan sikap ini dalam menjalani kehidupannya. ${ }^{17}$

Dalam pelaksanaan penanaman karakter disiplin dan tanggung jawab siswa dalam proses pembelajaran khususnya dalam mata pelajaran IPS Terpadu di kelas VIII C SMP Negeri 1 Jenangan, pasti terdapat kendala dalam pelaksanaannya. Berdasarkan hasil temuan lapangan pada saat penelitian yang peneliti laksanakan di SMP Negeri 1 Jenangan terdapat beberapa kendala dalam penanaman karakter disiplin dan tanggung jawab tersebut, yaitu antara lain sebagai berikut:

a. Faktor Keluarga

Keluarga merupakan faktor yang penting dalam perkembangan anak. Suasana, interaksi, maupun komunikasi dalam keluarga juga menentukan dalam pembentukan karakter anak. Kurangnya dukungan dan peran dari orang tua maupun keluarga dalam menanamkan karakter displin dan tanggung jawab merupakan kendala dalam penanaman karakter disiplin dan tanggung jawab di SMP Negeri 1 Jenangan.

b. Faktor Lingkungan

Lingkungan pergaulan ataupun lingkungan tempat tinggal dari peserta didik juga menjadi faktor yang menjadi kendala dalam penanaman karakter disiplin dan tanggung jawab siswa. Dalam pembelajaran daring waktu siswa lebih banyak dihabiskan di luar lingkungan sekolah, sehingga pergaulan dan pengaruh negatif dari lingkungan juga menjadi salah satu faktor kendala dalam penanaman karakter disiplin dan tanggung jawab siswa di SMP Negeri 1 Jenangan.

c. Pembelajaran Daring

Pelaksanaan pembelajaran daring atau pembelajaran jarak jauh juga berdampak dan menjadi kendala dalam upaya penanaman karakter disiplin dan tanggung jawab siswa di SMP Negeri 1 Jenangan. Pembelajaran secara daring kurang dapat mengakomodir upaya penanaman karakter kepada peserta didik kaitannya dalam ranah afektif. Seperti yang kita ketahui, bahwa pembelajaran daring selama ini lebih terfokus kepada pencapaian dalam ranah kognitif (pengetahuan).

17 Kurniawan, 31. 


\section{d. Faktor dari Diri Siswa}

Faktor internal yang berasal dari dalam diri siswa seperti kurangnya motivasi, kurang pahamnya siswa terkait apa itu pendidikan karakter, serta mindset peserta didik yang menganggap tanpa belajarpun akan tetap naik kelas juga menjadi salah satu faktor yang dapat menjadi kendala upaya penanaman karakter disiplin dan tanggung jawan di SMP Negeri 1 Jenangan.

\section{Solusi atas Kendala Penanaman Karakter Disiplin dan Tanggung Jawab Siswa dalam Proses Pembelajaran IPS Terpadu Kelas VIII C di SMP Negeri 1 Jenangan}

Menurut Saad \& Ghani, pemecahan masalah adalah suatu proses terencana yang harus dilakukan supaya mendapatkan penyelesaian tertentu dari sebuah masalah yang mungkin tidak didapat dengan segera. ${ }^{18}$ Menurut Matlin sebagaimana dikutip oleh Herlambang, pemecahan masalah dibutuhkan bilamana kita ingin mencapai tujuan tertentu tetapi cara penyelesaiannya tidak jelas. Dengan kata lain jika seorang siswa dilatih untuk menyelesaikan suatu masalah tertentu maka siswa itu menjadi mempunyai keterampilan yang baik dalam menghasilkan informasi yang sesuai, menganalisis informasi dan menyadari betapa perlunya meneliti kembali hasil yang diperolehnya. ${ }^{19}$

Dalam mengatasi kendala diperlukannya solusi yang dapat menjadi jalan keluar dari kendala tersebut. Berdasarkan hasil temuan lapangan yang peneliti dapatkan pada saat penelitian di SMP Negeri 1 Jenangan solusi dalam mengatasi kendala dalam penanaman karakter disiplin dan tanggung jawab yaitu sebagai berikut:

a. Kontrol dari Kepala Sekolah

Kepala SMP Negeri 1 Jenangan Ibu Sri Iswantini selalu aktif turun mengecek pelaksanaan pembelajaran dari kelas ke kelas lainnya setiap hari baik pembelajaran tatap muka secara terbatas ataupun mengontrol pelaksanaan pembelajaran secara daring. Kontrol dari kepala sekolah sangat diperlukan dalam upaya penanaman karakter disiplin dan tanggung jawab siswa di SMP Negeri 1 Jenangan.

Kontrol dari kepala sekolah tersebut diwujudkan dalam upaya selalu bekerjasama dengan orang tua/wali dalam penerapan pendidikan karakter peserta didik melalui wali kelas, guru BK dan humas dengan membentuk grup whatsapp wali/orang tua, memotivasi peserta didik untuk bergaul

${ }^{18}$ Ahmad A, Noor S. Saad, dan Sazeli Ab Ghani, "Mathematical Problem Solving Behavior of Succesful Problem Solvers," Jurnal Pendidikan Sains \& Matematik Malaysia, 2, no. 4.

19 Herlambang, "Analisis Kemampuan Pemecahan Masalah Matematika Siswa Kelas VII-A SMP Negeri 1 Kepahiang Tentang Bangun Datar Ditinjau Dari Teori Van Hielle,” Tesis : PPS Universitas Bengkulu, 2013. 
dan bersosial dengan lingkungan yang tepat agar tidak terkena pengaruh negatif, sanksi atas sikap tidak disiplin dan tidak tanggung jawab tersebut. Sebab peran dan kebijakan dari kepala sekolah juga menjadi salah satu faktor penentu dalam keberhasilan penanaman kedisiplinan dan tanggung jawab dari siswa-siswi SMP Negeri 1 Jenangan.

Kontrol yang dilakukan kepala SMP Negeri 1 Jenangan dalam melakukan evaluasi dan penilaian sekolah terhadap pelaksanaan pendidikan karakter di SMP Negeri 1 Jenangan yang dilakukan dengan cara:

1) Setiap hari Senin pada saat pelaksanaan upacara bendera selalu di evaluasi karakter-karakter peserta didik yang belum menerapkan pendidikan karakter secara maksimal.

2) Pada saat rapat dinas dilakukan pembahasan terkait evaluasi pelaksanaan pendidikan karakter.

3) Mengingatkan guru untuk selalu menanamkan nilai karakter kepada peserta didik baik dalam proses pembelajaran maupun melaui suri tauladan yang dicontohkan dalam tindakannya.

4) Memotivasi peserta didik dalam menerapkan pendidikan karakter

b. Peran Aktif Guru

Peran aktif dari Bapak/Ibu Guru menjadi salah satu solusi dan kunci keberhasilan dalam pelaksanaan penamanan karakter disiplin dan tanggung jawab siswa di SMP Negeri 1 Jenangan. Sebab gurulah yang setiap hari berinteraksi secara langsung kepada siswa baik dalam proses pembelajaran di dalam kelas maupun di luar kelas, serta salah satunya melalui contoh dan teladan yang baik kaitannya dengan kedisiplinan dan tanggung jawab yang dicontohkan akan berdampak pula terhadap pembentukan karakter disiplin dan tanggung jawab siswa khususnya di kelas VIII C SMP Negeri 1 Jenangan.

\section{PENUTUP}

Berdasarkan penelitian yang peneliti lakukan di SMP Negeri 1 Jenangan mengenai upaya guru mata pelajaran IPS dalam menanamkan karakter disiplin dan tanggung jawab siswa kelas VIII C di SMP Negeri 1 Jenangan tahun ajaran 2020/2021 dapat disimpulkan bahwa:

1. Upaya guru mata pelajaran IPS dalam menanamkan karakter disiplin dan tanggung jawab siswa di kelas VIII C SMP Negeri 1 Jenangan, berdasarkan hasil penelitian yang peneliti peroleh dari hasil wawancara, observasi maupun dokumentasi di SMP Negeri 1 Jenangan dengan menggunakan metode kualitatif. Terlihat bahwa upaya penanaman karakter disiplin dan tanggung jawab siswa oleh guru mata pelajaran IPS telah ditanamkan, hal 
itu tercermin dari proses pembelajaran mata pelajaran IPS Terpadu yang dilaksanakan secara daring melalui media pembelajaran Google Classroom dan pembelajaran tatap muka secara terbatas di kelas VIII C SMP Negeri 1 Jenangan. Ditemukan hasil bahwa siswa-siswi kelas VIII C SMP Negeri 1 Jenangan memiliki kedisiplinan dalam mengumpulkan tugas, mengikuti kegiatan pembelajaran, datang tepat waktu, dan disiplin dalam menerapkan protokol kesehatan, hal tersebut merupakan contoh kedisiplinan dan tanggung jawab yang telah ditanamkan di kelas VIII C SMP Negeri 1 Jenangan. Upaya guru mata pelajaran IPS dalam menanamkan karakter disiplin dan tanggung jawab yaitu melalui prinsip Contextual Teaching and Learning (CTL) yang dimana guru mengkaitkan antara materi yang dipelajarinya dengan situasi dunia nyata siswa.

2. Kendala dalam penanaman karakter disiplin dan tanggung jawab siswa dalam proses pembelajaran IPS terpadu di kelasVIII C SMP Negeri 1 Jenangan yaitu antara lain sebagai berikut

a. Faktor keluarga

Kurangnya dukungan dan peran dari orang tua maupun keluarga

b. Faktor lingkungan

Pergaulan dan pengaruh negatif dari lingkungan tempat tinggal siswa

c. Pembelajaran daring

Pembelajaran secara daring kurang dapat mengakomodir upaya penanaman karakter kepada peserta didik kaitannya dalam ranah afektif.

d. Faktor dari diri siswa

Kurangnya motivasi, kurang pahamnya siswa terkait apa itu pendidikan karakter, dan mindset dari peserta didik

3. Solusi atas kendala dalam penanaman karakter disiplin dan tanggung jawab siswa dalam proses pembelajaran IPS terpadu di kelasVIII C SMP Negeri 1 Jenangan yaitu antara lain sebagai berikut

a. Kontrol dari kepala sekolah

Kontrol yang dilakukan kepala SMP Negeri 1 Jenangan dalam melakukan evaluasi dan penilaian sekolah terhadap pelaksanaan pendidikan karakter di SMP Negeri 1 Jenangan yang dilakukan dengan cara:

1) Setiap hari senin pada saat pelaksanaan upacara bendera selalu di evaluasi karakter-karakter peserta didik yang belum menerapkan pendidikan karakter secara maksimal.

2) Pada saat rapat dinas dilakukan pembahasan terkait evaluasi pelaksanan pendidikan karakter. 
114 Amiruddin, Muhammad Widda Djuhan, Upaya Guru Mata Pelajaran IPS

3) Mengingatkan guru untuk selalu menanamkan nilai karakter kepada peserta didik baik dalam proses pembelajaran maupun melaui suri tauladan yang dicontohkan dalam tindakannya.

4) Memotivasi peserta didik dalam menerapkan pendidikan karakter

b. Peran aktif guru

Melalui contoh dan teladan yang baik yang diberikan oleh guru kepada siswa kaitannya dengan kedisplinan dan tanggung jawab . 


\section{DAFTAR PUSTAKA}

A, Ahmad, Noor S. Saad, dan Sazeli Ab Ghani. "Mathematical Problem Solving Behavior of Succesful Problem Solvers," Jurnal Pendidikan Sains \& Matematik Malaysia, 2, no. 4, (https://ejournal.upsi.edu.my/index.php, diakses 15 November 2020).

Ardy Wiyani, Novan. Pendidikan Karakter Berbasis Iman dan Taqwa. Yogyakarta: Teras, 2012.

Departemen Pusat Bahasa Depdiknas. Kamus Besar Bahasa Indonesia, 2008.

Depertemen Pendidikan Nasional. Kamus Besar Bahasa Indonesia. Jakarta: Balai Pustaka, 2007.

Hamalik, Oemar. Proses Belajar Mengajar. Jakarta: Bumi Aksara, 2012.

Herlambang. "Analisis Kemampuan Pemecahan Masalah Matematika Siswa Kelas VII-A SMP Negeri 1 Kepahiang Tentang Bangun Datar Ditinjau Dari Teori Van Hielle,” Tesis : PPS Universitas Bengkulu, 2013.

Koesoema, Doni. Pendidikan Karakter Strategi Mendidik Anak di Zaman Global. Jakarta: PT Gramedia Widiasarana Indonesia, 2007.

Kurniawan, Syamsul. Pendidikan Karakter: Konsepsi dan Implementasi secara Terpadu di Lingkungan Keluarga, Sekolah, Perguruan Tinggi, dan Masyarakat. Yogyakarta: Ar-Ruzz Media, 2013.

Mu'in, Fatchul. Pendidikan Karakter: Kontruksi Teoritik dan Praktik. Yogyakarta: Ar-Ruzz Media, 2011.

Muslich, Masnur. Pendidikan Karakter Menjawab Tantangan Krisis Multidimensional. Jakarta: Bumi Aksara, 2011.

Mustoip, dan Sofyan. "Implementation of Character Education," International Journal Pedagogy of Social Studies, 1 (2018), (https://ejournal.upi.edu/ index.php, diakses 15 November 2020).

Novitasari, Wiyanarti Erlina, dan Jupri. "The Implementation of Project Based Learning to Improve Students Responsibility in Social Studies Learning," International Journal Pedagogy of Social Studies, 2 (2018), (https://ejournal. upi.edu/index.php, diakses 15 November 2020). 
116 Amiruddin, Muhammad Widda Djuhan, Upaya Guru Mata Pelajaran IPS

Nurhadi. Pembelajaran Kontekstual (Contextual Teaching /CTL) dan Penerapannya dalam KBK. Malang: Universitas Negeri Malang, 2004.

Sartika, Dwi, Eva, dan Cik Ima. "Implementasi Nilai-Nilai Karakter Dalam Pembelajaran IPS Terpadu di SMP Utama Bakti Palembang," Prosding Seminar Nasional 20 Program Pascasarjana Universitas PGRI Palembang, 25 November 2017. (https://jurnal.univpgripalembang.ac.id/index.php/ Prosidingpps/article/view/1343, Diakses 15 November 2020).

Undang-Undang Nomor 20 Tahun 2003 tentang Sistem Pendidikan Nasional (Sisdiknas) Pasal 3.

Wawancara dengan Ibu Siti Supatmi pada hari jumat pagi tanggal 12 November 2020.

Zubaedi. Desain Pendidikan Karakter: Konsep dan Aplikasinya dalam Lembaga Pendidikan. Jakarta: Kencana Prenandamedia Group, 2011. 